Nayan M. Parekh, MS (ORL), FRCSI (ORL) Prashant R. Kashyap, MBBS, MS (ENT)

RIPAS Hospital Brunei Darussalam
Correspondence: Dr. Nayan M. Parekh

Consultant ENT Surgeon

Department of Otolaryngology

Level III, Specialist Building

RIPAS Hospital

Brunei Darussalam BA1710

Phone: +(673) 2232111 Ext 5316

Fax: $+(673) 22221085$

Email:drnayan11@gmail.com

The authors declared that this represents original material that is not being considered for publication or has not been published or accepted for publication elsewhere, in full or in part, in print or electronic media; that the manuscript has been read and approved by all authors, that the requirements for authorship have been met by each author, and that each author believes that the manuscript represents honest work.

Disclosures: The authors signed disclosures that there are no financial or other (including personal) relationships, intellectual passion, political or religious beliefs, and institutional affiliations that might lead to a conflict of interest.

\section{(ब) $\Theta$}

\title{
Crab Shell Impaction in the Larynx with Aphonia
}

\section{ABSTRACT}

Objective: To report a case of crab shell impaction at the glottic level presenting only as aphonia and cough.

\section{Methods:}

\author{
Design: Case Report \\ Setting: Tertiary Government Hospital \\ Patient: One
}

Results: A 36-year-old male, who presented in emergency with sudden aphonia after a meal, was found to have crab shell with leg spines impacted at the glottic level. Due to its large size, ragged edges and the sharp spines stuck in the tissue, endoscopic removal needed a prior tracheostomy. All pieces were extracted, with no bleeding, laceration or tissue damage. The patient completely recovered with normal vocal folds and a normal voice at follow up.

Conclusion: Our experience suggests that an impacted foreign body may warrant a tracheostomy to secure the airway prior to extraction and avoid any possible complications including laryngeal injury.

Keywords: foreign body, larynx, crab shell, loss of voice

Foreign bodies in the aerodigestive tract are among the most common ear, nose and throat (ENT) emergencies worldwide and may pose major diagnostic and management challenges. They are more common in children, the intellectually challenged or mentally ill individuals.,2 Accidental ingestion or inhalation is the most common cause in older children and adults but the chance of accidental inhalation is rarer than that of ingestion as the physiologic sphincter function of the larynx efficiently protects the lower respiratory tract.' Most aspirated foreign bodies pass through the laryngeal inlet and lodge lower in the airway and laryngeal impaction is very rare ${ }^{2,3}$ occurring in $1 \%$ to $18 \%$ of all patients. ${ }^{4-7}$ When inhaled, large, sticky, thorny or irregularly-shaped foreign bodies may lodge in the larynx $x^{1,2}$ and become life threatening due to spasm or direct obstruction leading to airway compromise, posing a great management challenge. We report one such case.

\section{CASE REPORT}

A 36-year-old man presented in Accident and Emergency at RIPAS Hospital (the only tertiary care hospital in Brunei Darussalam) with sudden-onset loss of voice which coincided with eating lunch that included crab legs. He was anxious, sweating and coughing relentlessly on presentation but had no stridor or respiratory distress. He was afebrile with blood pressure of $160 / 110 \mathrm{mmHg}$ (not a known hypertensive), oxygen saturation of $100 \%$ on air and normal neurological examination. The case was immediately referred to the ENT surgeon on call. Flexible laryngoscopy revealed a thin, bony, conical crab shell with jagged free projecting margins circumferentially stuck at the level of the glottic opening. The bony shell had a central opening through which the patient appeared to be breathing comfortably but was unable to phonate. (Figure 1) 


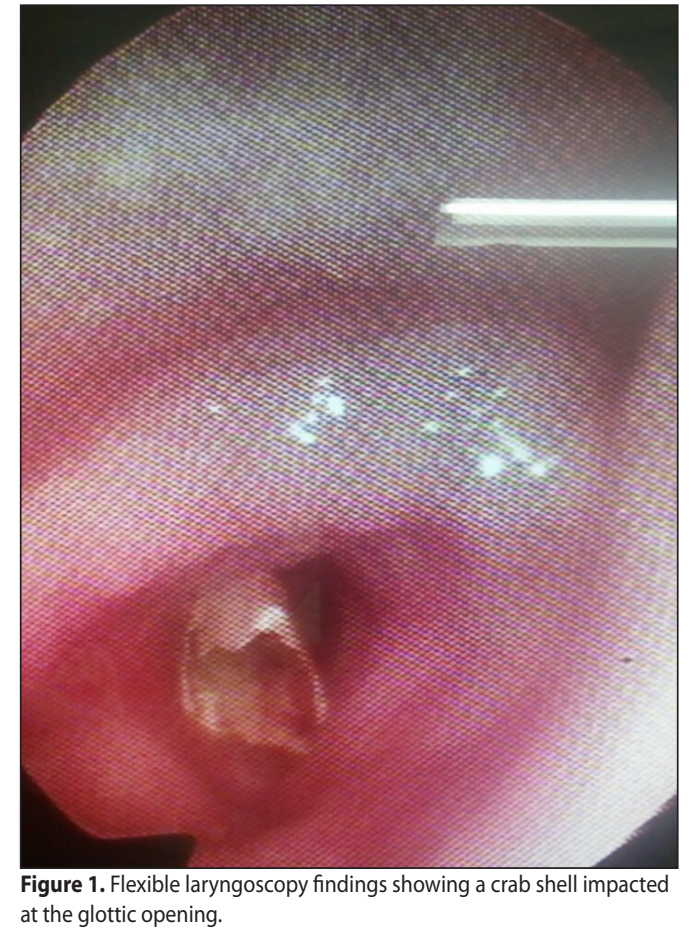

The patient was immediately posted as an emergency case for removal of the foreign body by direct laryngoscopy under general intravenous anaesthesia with spontaneous breathing. What was thought to be a fairly straightforward removal of the conical crab shell seen on flexible laryngoscopy turned out to be difficult on direct laryngoscopy and subsequent microlaryngoscopy. The crab shell could not be dislodged despite several attempts as it was very firmly and almost circumferentially impacted in the larynx at the glottic level, and only a few pieces of the thin brittle bony shell came out with each attempt at removal.

As the procedure prolonged beyond 30 minutes and with endotracheal intubation not possible, it became imperative to do a tracheostomy to maintain anaesthesia and facilitate a safe and smooth procedure.

The shell could not be removed as a single piece or as intact as possible as it was firmly impacted and brittle and kept breaking into pieces with each attempt to grasp and remove it. It was therefore removed piecemeal ensuring all the pieces were removed under direct vision. (Figure 2) There was no bleeding, laceration or tissue damage encountered. The most notable parts of the shell were the very sharp and curved crab leg spines -3 in number. These spines had firmly anchored into the tissue on the under surface of the vocal folds making removal very difficult. (Figure 3) These were almost the final parts to come out.

The patient was transferred to the ward following the procedure with an unremarkable course to recovery. Flexible laryngoscopy on the second day revealed mobile vocal folds with minimal edema. The

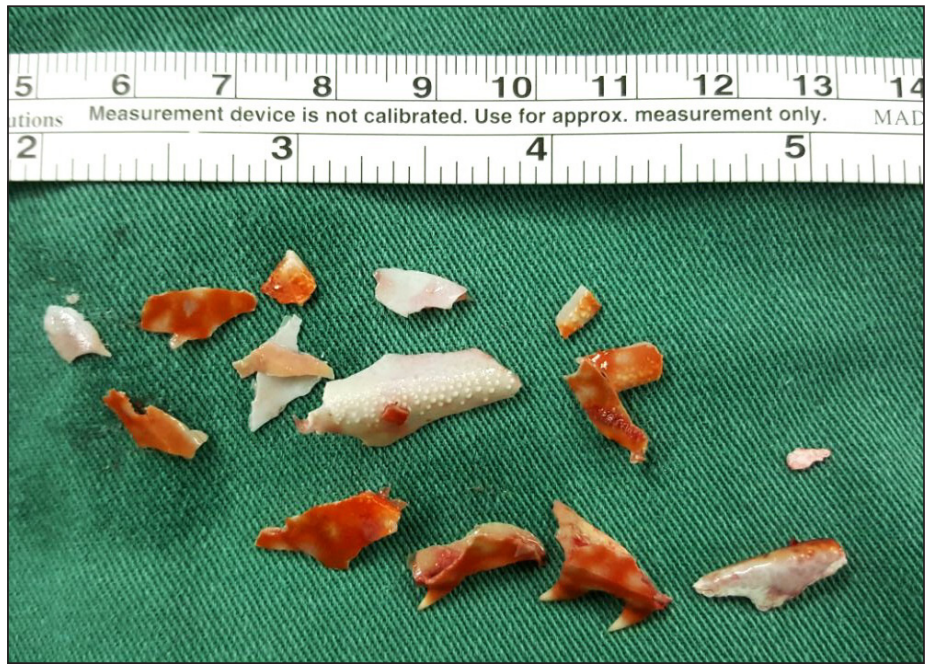

Figure 2. Crab shells fragments removed piecemeal from larynx.

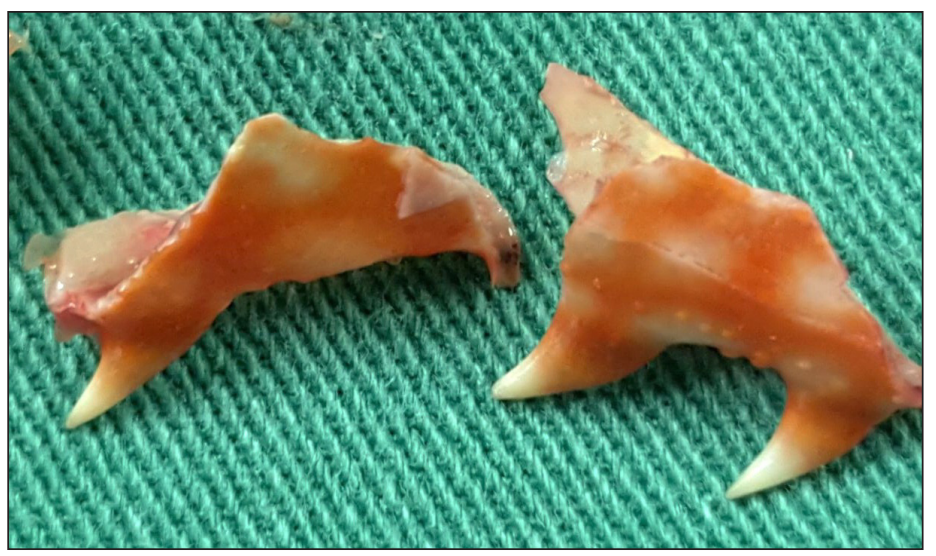

Figure 3. Close-up view of crab shell fragments with sharp spines which anchored into the undersurface of the vocal folds.

tracheostoma was closely approximated with tight dressing while patient was decannulated on the third postoperative day and he was able to phonate well and normally with no respiratory distress. He was discharged on the fourth postoperative day and followed up after a week by which time the tracheostoma had completely closed. Endoscopy then revealed bilaterally normal, mobile vocal folds with a normal voice.

\section{DISCUSSION}

Commonly inhaled foreign bodies can be organic or non-organic. The commonest inhaled organic foreign bodies reported are peanuts, but others include fruit seeds, fish bones, chicken bones and mutton pieces. ${ }^{2}$ All these can cause immediate or delayed tissue reaction and edema to worsen the airway obstruction. Non-organic and metallic items when aspirated may cause minimal or no tissue reaction. These include latex balloons plastic toys, pieces of dentures, stones, earrings, coins and safety pins. ${ }^{2}$ 


\section{CASE REPORTS}

The inhaled foreign bodies settle in hypopharynx (5\%), larynx $(2-9 \%)$, trachea $(12 \%)$, or bronchi $(83 \%)$. $^{3}$ Reviewing other series reporting tracheobronchial foreign bodies - mainly in children - the reported incidence of impaction in the larynx varies in range from $1 \%$ to $18.75 \%$ in various studies. ${ }^{4.7} \mathrm{~A}$ foreign body rarely settles in the larynx due to its strong inherent protection and tends to enter the hypopharynx more commonly or passes down in the tracheobronchial tree. ${ }^{8}$ Only those which are too large, sharp or irregular can get lodged at the glottic level. ${ }^{1,2}$

A patient with laryngeal foreign body can present with sudden dyspnea and stridor, sudden airway obstruction including cyanosis, bouts of cough, hoarseness or aphonia, throat pain or discomfort and dysphagia to odynophagia. ${ }^{2}$ The severity of clinical presentation will depend on site of impaction, suddenness and degree of obstruction, size, shape and type of foreign body - including organic or non-organic, age of the patient and possible laryngeal irritation or spasm. ${ }^{2}$

Unusual foreign bodies in the larynx, causing no or minimal breathing issues and presenting mainly with voice changes of variable duration or throat discomfort have included a piece of sticker, ${ }^{2}$ coin, ${ }^{9}$ metallic clip of a crepe bandage, ${ }^{9}$ a leech ${ }^{3}$ denture, ${ }^{10}$ denture fragment, ${ }^{1}$ a bone piece, ${ }^{8}$ sewing needle, ${ }^{11}$ bird bone, ${ }_{1}^{12}$ open safety pin $^{13}$ metallic screw, ${ }^{14}$ ballpen metal tip, ${ }^{14}$ and a paper pin. ${ }^{15}$

Our case had a clear history of eating crab after which the complaints started, clearly pointing to a possible foreign body. This was easily confirmed by flexible laryngoscopy. In view of the clinical picture, an $\mathrm{X}$-ray was not considered necessary. However, the irregular surface and strong sharp spines had deeply embedded the crab shell, impacting at the glottic level. A tracheostomy was really decided for at that stage for adequate ventilation of the patient and to avoid any possible laryngospasm and/or further airway compromise while manipulating the foreign body at the glottic level. Only after the airway was fully secured and ventilation stabilised was the shell fully removed in pieces with utmost care to avoid any injury. In retrospect, any forceful attempt to remove the foreign body without a tracheostomy would have been largely unsuccessful due to the sharp spines impacted under the vocal fold level and would have led to variable degrees of laryngeal injury.

Our report demonstrates a serious and potential life threatening medical emergency caused by the crab shell impaction in the throat. Apparently, while the patient was trying to suck in the pink soft meaty part of the claw, the shell must have detached as well and was accidentally sucked in. This is reminiscent of the pathophysiology of a previously-reported aspiration of embryonated duck shell while slurping the soup, and may explain the reported high incidence of pin aspiration among young Islamic women who hold pins with their lips while arranging their headscarf, or of needle darts among young boys. $^{16}$

We did not find any literature on crab shell in the airway. However, there are two relevant newspaper reports of a $2 \mathrm{~cm}$ size crab shell ${ }^{17}$ and a pointed piece of crab shell ${ }^{18}$ impacted in the esophagus of a 55-year-old man and lady respectively, that were both successfully removed in hospitals in India.

In conclusion, laryngeal foreign bodies are rare particularly in adults and their presentation with aphonia only and no respiratory distress is extremely rare. Our case of crab shell impaction at the glottic inlet is one such rare foreign body presenting only with aphonia. Our experience suggests that a compromised airway or strongly impacted foreign body may warrant a tracheostomy to secure the airway prior to foreign body extraction, and avoid any possible complications including laryngeal injury.

\section{REFERENCES}

1. Kothari S, Vijay A. A rare glottic foreign body with unusual presentation. World Articles in Ear Nose and Throat. 2013 Mar 15;6-1. [cited 2018 Mar 8]. Available from http://www.waent.org/ archives/2013/Vol6-1/20130217-glottic-foreign-body/glottic-foreign-body-manuscript.htm.

2. Kansara AH, Shah HV, Patel MA, Manjunatharao SV. Unusual case of laryngeal foreign body; Indian J Otolaryngolog Head Neck Surg. 2007 Apr 26;59(1):63-65. doi: 10.1007/s12070-007 0019-0 PMCID: PMC3451719; PMID: 23120391.

3. Ganguly SN, Reddy NS, Shrestha A, Shah D, Shakya N, Acharya S. Unusual case of laryngeal foreign body. J College Med Sci Nepal. 2010 Aug 24; 6(1):45-46. doi: http://dx.doi.org/10.3126/ jcmsn.v6i1.3601 [cited 2018 Mar 8]. Available from: https://www.nepjol.info/index.php/JCMSN/ article/view/3601/3100.

4. McGuirt WF, Holmes KD, Feehs R, Browne JD. Tracheobronchial foreign bodies.; Laryngoscope. 1988 Jun;98(6):615-618. doi: 10.1288/00005537-198806000-00007 PMID:3374237.

5. Rothman BF, Boeckman CR. Foreign bodies in the larynx and tracheobronchial tree in children. A review of 225 cases. Ann Otol Rhinol Laryngol. 1980 Sep-Oct; 89(5): 434-436. doi: 10.1177/000348948008900512 PMID:7436247.

6. Silva $A B$, Muntz HR, Clary R. Utility of conventional radiography in the diagnosis and management of pediatric airway foreign bodies. Ann Otol Rhinol Laryngol. 1998 Oct; 107(10): 834-838. doi: 10.1177/000348949810701004 PMID:9794611.

7. Razi Hadi A, Said H, Ahmad K. Foreign bodies in the laryngotracheobronchial tree. Med J Malaysia. 1988 Mar; 43(1):74-83. PMID:3244325.

8. Veccham C, Gouripeddi S. Silent laryngeal foreign body. Journal of Evolution of Medical and Dental Sciences. 2015 Jun 18;4(49):8609-8611. doi: 10.14260/jemds/2015/1245; Available from: https://jemds.com/latest-articles.php?at_id=8134.

9. Hada MS, Samdhani S, Chadha V, Harshvardhan RS, Prakash M. Laryngeal foreign bodies among adults. J Bronchology Interv Pulmonol. 2015 Apr; 22(2):145-147. doi: 10.1097/ LBR.0000000000000056 PMID:25887012.

10. Jeing YD, bin Md Nasir AM, Gendeh BS. Unusual glottic denture impaction: A case report Asian Journal of Oral and Maxillofacial Surgery; 2011 Mar; 23(1):50-52. doi:10.1016/j. ajoms.2010.10.010.

11. Chouhan M, Yadav JS, Bakshi J. Unusual presentation of foreign body in larynx. Egyptian J Ear Nose Throat Allied Sci. 2012 Mar; 13(1):61-63. doi:10.1016/j.ejenta.2012.02.002 [cited 2018 Mar 8]. Available from: https://doi.org/10.1016/j.ejenta.2012.02.002.

12. Ambu VK, Narayanan P, Ratnasingam V. Neglected laryngeal foreign body. The Journal of Laryngology \& Otology. 2001 Sep; 115(9): 740-742. doi:10.1258/0022215011908801 [cited 2018 Mar 8]. Available from: https://doi.org/10.1258/0022215011908801.

13. Baliarsingh D, Rath A, Hota A, Panigrahi R. Open safety pin in larynx: A case report and review of literature. Int J Otolaryngol Clin. 2017 Jan-Apr; 9(1): 21-24. doi:10.5005/jp-journals-10003-1255.

14. Hada MS, Chadda V, Mishra P, Gupta P, Grover M. Unusual metallic foreign bodies in the larynx two case reports. Indian J Pediatr. 2012 Aug; 79(8): 1100-1102. doi: 10.1007/s12098-011-0621-8 PMID: 22237635.

15. Bir Singh G, Abrol R, Dass A. An unusual foreign body in the larynx in an adult. Otolaryngol Head Neck Surg. 2005 Oct; 133(4): 639. doi: 10.1016/j.otohns.2004.09.059 PMID:16213945.

16. Lapena JF Jr. Embryonated duck ("balut") eggshell aspiration in a one-year-old boy. Singapore Med J. 2009 May;50(5):e170-1. PMID:19495500.

17. Varanasi A. Doctors fish out crab shell from 55 -year-old Mumbai man's throat. Mid-day.com 2014 May 14. [cited 2018 June 22]. Available from: http://www.mid-day.com/articles/doctorsfish-out-crab-shell-from-55-year-old-mumbai-man-s-throat/15312153.

18. DNA Correspondent. Eating crab leaves Boisar woman shell-shocked. DNA India. 2013 Mar 29 [cited 2018 June 22]. Available from: http://www.dnaindia.com/mumbai/report-eating-crableaves-boisar-woman-shell-shocked-1816722. 